\title{
Celowość budowy głębokowodnego portu morskiego na środkowym Pomorzu Studium wstępne
}

\section{Tadeusz Wójcicki}

\section{STRESZCZENIE}

Główne porty w Polsce są położone niefortunnie, wyłącznie przy zachodnim albo wschodnim krańcu polskiego wybrzeża Bałtyku, czyli przy ujściu Odry albo w rejonie ujścia Wisły do morza, i są odległe od siebie o ok. 280-290 km w linii prostej. Warto zatem rozważyć zasadność budowy czwartego portu głębokowodnego, położonego mniej więcej pośrodku między nimi, a więc gdzieś na środkowym Pomorzu, najlepiej na odcinku wybrzeża między głównymi miastami tej części Pomorza, między Kołobrzegiem a Koszalinem.

W tym celu w niniejszym opracowaniu przeanalizowano uwarunkowania planistyczne, transportowe, przyrodnicze i hydrograficzne, przedstawiono argumenty za i przeciw takiej inwestycji, a w końcu - po stwierdzeniu celowości inwestycji - podano orientacyjne miejsca lokalizacji inwestycji, oceniono je w sposób wielokryterialny i wskazano lokalizację optymalną.

Z wykonanej analizy SWOT wynika, że pozytywne aspekty budowy nowego portu zdecydowanie przeważają nad negatywami, wobec czego wstępnie przyjęto, że realizacja inwestycji jest celowa, przy czym zastrzeżono się, że wnioski te odnoszą się wyłącznie do założonego scenariusza dalszego szybkiego rozwoju gospodarki morskiej w Polsce.

Przyjmując celowość budowy nowego portu morskiego jako założenie wstępne, określono generalny program inwestycji, przewidując powstanie $\mathrm{w}$ okresie docelowym $\mathrm{w}$ ramach portu dwóch baz kontenerowych, po jednym terminalu gazowym i naftowym, a także bazy promowej oraz nabrzeża dla statków pasażerskich. Oznacza to, że po zakończeniu takiej inwestycji teren portu zajmowałby ok. $6 \mathrm{~km}^{2}$ powierzchni, w tym ok. $3 \mathrm{~km}^{2}$ powierzchni przypadałoby na baseny portowe wraz z obrotnicami, a ok. $2 \mathrm{~km}^{2}$ na sztuczny półwysep z nabrzeżami, składowiskami, drogami i bocznicami kolejowymi.

Określono wstępnie następujące warianty ogólnych lokalizacji analizowanego przedsięwzięcia: „Kołobrzeg”, ,Pleśna”, „Gąski”, „Mielenko" oraz „Jezioro Jamno", a następnie zebrano podstawowe dane charakteryzujące każdy wariant pod względem hydrologicznym, technicznym, ekonomicznym i środowiskowym. W rezultacie wykonanej analizy wielokryterialnej okazało się, że zdecydowanie najlepszą lokalizacją portu morskiego będzie wariant 5. „Jezioro Jamno”, a pod uwagę można również brać drugą w kolejności najlepszą lokalizację, tj. wariant 4. "Mielenko”. Oba te warianty wzmacniają funkcję osadniczą miasta Koszalin, co jest w pełni zgodne z planem wojewódzkim - planowany biegun wzrostu w Koszalinie.

Słowa kluczowe: transport wodny, budowa portów morskich, optymalizacja lokalizacji inwestycji transportowych, studia wykonalności, hydrologia, ochrona środowiska 


\section{Wprowadzenie}

Największe porty morskie położone nad Bałtykiem mają nabrzeża głębokowodne, co zapewnia im przewagę w konkurencji z innymi portami z uwagi na możliwość obsługi największych statków. Zanurzenie statków wpływających na Bałtyk jest limitowane głębokością Cieśnin Duńskich, w których najgłębszy tor wodny umożliwia ruch statków o zanurzeniu do $15 \mathrm{~m}$. W związku z tym bałtyckie portowe nabrzeża głębokowodne to nabrzeża, przy których mogą cumować statki o tym zanurzeniu maksymalnym.

W Polsce nabrzeża głębokowodne ma jedynie port w Gdańsku (pow. gdański). Znajdują się w jego części zewnętrznej, najbardziej wysuniętej w morze, zwanej Portem Północnym, do której z otwartego morza prowadzi osobny tor wodny o głębokości $17 \mathrm{~m}$. Zarząd portu Gdańsk podaje, że taka głębokość toru umożliwia cumowanie przy pirsach statków o długości od 220 m do 765 m i zanurzeniu wynoszącym do 15 m [www.portgdansk.pl]. Niewątpliwie tak korzystne warunki hydrologiczne sprawiły, że port w Gdańsku jest największym polskim portem morskim i czwartym największym portem bałtyckim z przeładunkami wynoszącymi w 2019 r. 52,2 mln ton [www.rynekinfrastruktury.pl].

W kolejnych największych portach morskich Polski maksymalne dopuszczalne zanurzenie wpływających statków wynosi w Gdyni (pow. gdyński) i Świnoujściu (pow. świnoujski) 13,5 m, a w Szczecinie (pow. szczeciński) 9,15 m. Obecnie trwają prace nad pogłębieniem toru wodnego ze Świnoujścia do Szczecina do głębokości 12,5 m, co pozwoli na cumowanie przy niektórych nabrzeżach portu Szczecin statków o zanurzeniu do 11,05 m. Zarząd zespołu portów Szczecin-Świnoujście informuje, że „warunkiem utrzymania przez port w Szczecinie budowanej przez lata pozycji konkurencyjnej jest realizacja pogłębienia toru wodnego" [www.port.szczecin.pl].

Przeładunki w większości polskich portów morskich dynamicznie wzrastały w ujęciu wieloletnim, przed wystąpieniem pandemii. Przykładowo, port w Gdańsku zanotował wzrost przeładunków towarów z 40,6 mln ton w 2017 r. do 49,0 mln ton w 2018 r. [trojmiasto. wyborcza.pl], czyli nastąpił wzrost przeładunków o 20,7\%, rekordowy dla portów bałtyckich. W związku z korzystną sytuacją gospodarczą kraju, mimo pandemii, skutkującą m.in. wzrostem przeładunków w portach morskich w przyszłych latach, zarządy największych polskich portów nad Bałtykiem planują budowę nowych, zewnętrznych części swoich portów. I tak Gdańsk planuje budowę Portu Centralnego między ujściem Wisły Martwej do morza a istniejącym Portem Północnym, Gdynia zamierza zbudować Port Zewnętrzny w formie sztucznego półwyspu na morzu, sięgającego daleko za falochron zewnętrzny, a Świnoujście ma plany budowy Terminala Kontenerowego w porcie zewnętrznym bezpośrednio na wschód od Gazoportu, obsługującego terminal LNG. Nowe części portów w Trójmieście będą obsługiwać statki o zanurzeniu do $15 \mathrm{~m}$ [www.portalmorski.pl], a w Świnoujściu - o zanurzeniu do 12,5 m [www.eswinoujscie.pl], a docelowo do $15 \mathrm{~m}$ [www.portalmorski.pl/porty-logistyka/42174]. W celu ułatwienia tych inwestycji rząd zgłosił a Sejm uchwalił ustawę o inwestycjach w zakresie budowy portów zewnętrznych [Ustawa z dnia 9 sierpnia 2019 r.]. 
Jeśli powyższe inwestycje dotyczące portów zewnętrznych zostaną zrealizowane, to Polska będzie mieć trzy pełnowartościowe porty głębokowodne, leżące niefortunnie wyłącznie przy zachodnim albo wschodnim krańcu polskiego wybrzeża Bałtyku, czyli przy ujściach wielkich rzek: Odry i Wisły. Porty te są odległe od siebie o ok. 280-290 km w linii prostej. W takiej sytuacji warto rozważyć zasadność budowy czwartego portu głębokowodnego, położonego mniej więcej pośrodku między nimi, a więc gdzieś na środkowym Pomorzu, najlepiej na odcinku wybrzeża między głównymi miastami tej części Pomorza, a więc między Kołobrzegiem (pow. kołobrzeski) a Koszalinem (pow. koszaliński). W tym celu trzeba przeanalizować uwarunkowania planistyczne, transportowe, przyrodnicze i hydrologiczne, przedstawić argumenty za i przeciw takiej inwestycji, a w końcu - w razie stwierdzenia celowości inwestycji - podać orientacyjne miejsca lokalizacji inwestycji, ocenić je i wskazać wstępnie lokalizację optymalną.

\section{Podstawy planistyczne inwestycji}

Pomysł budowy portu głębokowodnego na środkowym Pomorzu, podobnie jak i pozostałych portów tego typu w Gdańsku, Gdyni i Świnoujściu, nie został uwzględniony w dokumentach dotyczących planowania przestrzennego, gdyż większość tych dokumentów powstała w okresie względnego zastoju w gospodarce morskiej i nie przewidziano wtedy późniejszego dynamicznego rozwoju transportu morskiego.

Niemniej jednak idea takiego portu jest zgodna z zasadami przedstawionymi w aktualnych dokumentach planistycznych. I tak w Koncepcji Przestrzennego Zagospodarowania Kraju 2030 (KPZK 2030) z 2011 r. [Uchwała RM 2012] w rozdziale dotyczącym celów polityki przestrzennej kraju czytamy na str. 86, że „dla zapewnienia efektywnego wykorzystania potencjału terytorium całej Polski polityka przestrzennego zagospodarowania musi dążyć do zapewnienia spójności terytorialnej kraju w różnych wymiarach przestrzennych, wykorzystując kształtującą się policentryczną sieć metropolii". Precyzując ten cel, dalej na str. 88 określono cel nr 2.1 jako „Wspomaganie spójności w układzie krajowym: Pomorze Środkowe - Polska Zachodnia - Polska Centralna - Polska Wschodnia". Jednocześnie na str. 103 KPZK 2030 czytamy: „W odniesieniu do systemu transportowego polityka przestrzennego zagospodarowania kraju przede wszystkim będzie zmierzać do poprawy dostępności terytorialnej kraju w różnych skalach przestrzennych. (...) Jako najważniejsze traktowane będą inwestycje transportowe służące poprawie dostępności wewnętrznej i zewnętrznej kraju, przynoszące wartość dodaną w postaci zapewnienia spójności systemu transportowego, realizowanego w warunkach zrównoważonego rozwoju". Z tych zapisów jasno wynika, że idea nowego portu na środkowym Pomorzu wpisuje się doskonale w przyjętą przez rząd politykę transportowa zakładającą polepszenie spójności (dostępności) zewnętrznej kraju oraz w politykę przestrzenną w zakresie polepszenia spójności środkowego Pomorza z pozostałymi regionami kraju. 
Idea portu na środkowym wybrzeżu kraju jest również, co do zasady, zgodna z aktualnym Planem Zagospodarowania Przestrzennego Województwa Zachodniopomorskiego z $2010 \mathrm{r}$. (PZPWZ) [rbgp.pl], choć nie jest tam oczywiście opisana wprost, bo PZPWZ musi być zgodny z KPZK 2030. Na str. 195 PZPWZ cel strategiczny zagospodarowania przestrzennego województwa określono jako „zrównoważony rozwój przestrzenny województwa służący integracji przestrzeni regionalnej z przestrzenią europejską i krajowa spójności wewnętrznej województwa, zwiększeniu jego konkurencyjności oraz podniesieniu poziomu i jakości życia mieszkańców do średniego poziomu w Unii Europejskiej”. Przyjęto tamże, że „do realizacji tego celu należy, m.in.:

- $\quad$ wpływać na kształtowanie w województwie policentrycznej sieci osadniczej z biegunami wzrostu w Szczecinie i Koszalinie, wzmacniać powiązania między tymi miastami,

- rozwijać system transportowy zintegrowany z systemem krajowym i europejskim, zapewniający spójność wewnętrzną województwa".

Z powyższych ustaleń rozwojowych wynika, że ewentualna budowa portu morskiego na środowym Pomorzu wzmocniłaby realizację nakreślonych celów rozwoju przestrzennego województwa zachodniopomorskiego, w tym zwłaszcza w zakresie postulatu integracji systemu transportu w województwie z systemem europejskim. Jednocześnie, aby zrealizować pełniej postulat wzmocnienia wojewódzkich biegunów wzrostu, nowy port powinien być wybudowany niedaleko miasta Koszalin, które PZPWZ wyznacza jako drugi biegun wzrostu obok Szczecina.

\section{Podstawy transportowe inwestycji}

Do nowego portu w rejonie Kołobrzegu - Koszalina powinny prowadzić wygodne drogi oraz linie kolejowe. Pod tym względem sytuacja wygląda korzystnie, gdyż zarówno Kołobrzeg jak i Koszalin są węzłami kolejowymi i drogowymi, a między tymi miastami istnieje linia kolejowa, z odgałęzieniem do Mielna, (pow. koszaliński). Linia ta biegnie wzdłuż wybrzeża morskiego, a jej odległość od brzegu morskiego waha się od 0,7 km do 5,5 km na odcinku Kołobrzeg - Mielno, zwiększając się do ok. 9 km na wysokości Koszalina. Do podłączenia do sieci kolejowej nowego portu, w potencjalnej lokalizacji między Kołobrzegiem a Koszalinem, wystarczy wybudować nową krótką linię kolejową (łącznicę, bocznicę) o długości w przedziale od ok. $1 \mathrm{~km}$ do ok. $9 \mathrm{~km}$.

W zakresie transportu drogowego sytuacja wygląda jeszcze korzystniej, gdyż w 2019 r. zakończono budowę drogi ekspresowej S6 na odcinku Szczecin - Koszalin. Droga ta na odcinku Kołobrzeg - Koszalin przebiega wzdłuż wybrzeża Bałtyku w odległości od brzegu morskiego w granicach 3,5-8,5 km. Bez większych problemów nowy port można będzie zatem podłączyć do tej nowej drogi.

Nowy port powinien mieć dogodne połączenia drogowe i kolejowe z resztą kraju, w tym zwłaszcza z regionami kraju położonymi w głębi lądu. Tutaj sytuacja wygląda korzystnie, gdyż zarówno Kołobrzeg jak i Koszalin są połączone liniami kolejowymi z Białogardem 
(pow. białogardzki), odległym od morza o ok. 27 km, skąd biegnie linia kolejowa w głąb lądu do Piły (pow. pilski) i Poznania (pow. poznański), co zapewni dogodny transport kolejowy między portem a zachodnią Polską. Z Piły prowadzi linia kolejowa do Bydgoszczy (pow. bydgoski), co zapewni dogodny ruch kolejowy w kierunku wschodniej Polski.

Najważniejszym jednak argumentem za lokalizacją nowego portu morskiego na Pomorzu Środkowym jest planowana sieć dróg szybkiego ruchu w Polsce, z której wynika, że oprócz utworzenia dogodnych dróg dojazdowych do istniejących dużych portów morskich (S3, S10, A1, S7, S16) planuje się budowę drogi ekspresowej S11 z Koszalina do Piły, Poznania i Katowic (pow. katowicki). Zrealizowanie tej drogi znacząco poprawi dojazd na środkowe Pomorze zarówno z zachodniej Polski (S11 i S5), jak i Polski wschodniej (S11, S10, S8 i S17).

Obecny potencjał społeczno-gospodarczy rejonu koszalińsko-kołobrzeskiego, zamieszkanego przez ok. 300 tys. osób, w tym 154 tys. osób w dwóch głównych miastach rejonu, jest za mały, aby wykorzystać w pełni drogę S11. Jednocześnie na istniejących już drogach prowadzących do istniejących głównych portów morskich kraju (Szczecin, Świnoujście, Gdynia i Gdańsk) notuje się już wysokie natężenia ruchu, ograniczające prędkość jazdy samochodowej. Budowa analizowanego nowego portu morskiego spowodowałaby niewątpliwie lepsze wykorzystanie drogi S11, bo część strumienia towarów i pasażerów zmieniłaby kierunek $\mathrm{z}$ istniejących portów do nowego portu. Podobna sytuacja miałaby miejsce $\mathrm{w}$ transporcie kolejowym.

Reasumując, należy stwierdzić, że pod względem koniecznego podłączenia do sieci transportowych inwestycja nie napotka większych przeszkód, niezależnie od szczegółowej lokalizacji w pasie od Kołobrzegu do Koszalina, a z punktu widzenia transportu w skali krajowej (ponadregionalnej) nowy port ma jak najbardziej sens, gdyż równomierniej rozłoży ruch dojazdowy do głównych portów morskich Polski, w tym zwłaszcza pozwoli dociążyć planowaną drogę ekspresową S11 Koszalin - Poznań oraz linie kolejowe z Kołobrzegu/Koszalina przez Białogard do Poznania i Bydgoszczy.

\section{Podstawy ekologiczne inwestycji}

Zgodnie z przepisami prawa ochrony środowiska budowa dużego portu morskiego nie powinna znacząco oddziaływać na środowisko. W związku z tym wskazane jest zlokalizowanie takiej inwestycji poza terenami prawnie chronionymi, w tym zwłaszcza poza obszarami sieci Natura 2000, a jeżeli nie jest to możliwe, to ograniczenie takich kolizji do minimum. W rejonie kołobrzesko-koszalińskim wody przybrzeżne są w całości chronione jako obszar specjalnej ochrony ptaków „Zatoka Pomorska” (PLB990003), a więc kolizja portu z tym obszarem jest nieunikniona [geoserwis.gdos.gov.pl]. Można będzie jednak wykazać, że przy zastosowaniu pewnych środków łagodzących budowa portu na tym obszarze nie spowoduje znaczących oddziaływań negatywnych na chronione tam ptaki, co ma związek m.in. z dużą powierzchnią tego obszaru $-3091 \mathrm{~km}^{2}$. 
Inaczej rzecz ma się ze znajdującymi się na lądzie specjalnymi obszarami ochrony siedlisk pod nazwami „Trzebiatowsko-Kołobrzeski Pas Nadmorski” (PLH320017) oraz „Jezioro Bukowo" (PLH320041), z którymi niektóre lokalizacje portu mogą kolidować. Tutaj w przypadku kolizji należy założyć ewentualne zniszczenie tylko niewielkich skrajnych części tych obszarów, co wyklucza z lokalizacji portu odcinki wybrzeża: (1) na zachód od Kołobrzegu, (2) między Kołobrzegiem a Ustroniem Morskim (pow. kołobrzeski) oraz (3) na wschód od Łazów (pow. koszaliński, gm. Mielno), a w przypadku odcinków Ustronie Morskie - Gąski (pow. koszaliński, gm. Mielno) oraz Mielno - Łazy, gdzie wystąpi niewielka kolizja z tymi obszarami, zmusza do zachowania ostrożności przyrodniczej i wykonania dalszych szczegółowych analiz oddziaływania na chronioną przyrodę.

Wszystkie możliwe lokalizacje portu głębokowodnego na środkowym Pomorzu będą obejmować w części również tereny objęte ochroną w formie Obszaru Chronionego Krajobrazu pn.: „Koszaliński Pas Nadmorski”. Jednak stopień ochrony tego obszaru jest stosunkowo niski, a inwestycje celu publicznego, a więc także analizowana budowa portu, są dopuszczone do realizacji na takim obszarze bez istotnych ograniczeń.

Reasumując, można stwierdzić, że najmniej kolizyjna przyrodniczo lokalizacja portu to odcinek wybrzeża między Gąskami a Mielnem, a warunkowo można rozszerzyć lokalizację do nieco dłuższego odcinka między Ustroniem Morskim a Łazami. Jednak jeśli wziąć pod uwagę kolizje inwestycji z obszarami zabudowy miejscowości nadmorskich, to obszar ekologicznych poszukiwań lokalizacyjnych zawęża się do odcinków wybrzeża między tymi miejscowościami, gdzie brak jest zwartej zabudowy albo zabudowa jest niepełna, rozproszona. Jedynie przez takie zawężenie poszukiwań lokalizacyjnych osiągnie się złagodzenie konfliktów ze społecznościami lokalnymi do poziomu akceptowalnego. W pasie nadmorskim jest silnie rozwinięta funkcja osadnicza powiązana ściśle z funkcją turystyczną terenu, co nie jest korzystne z punktu widzenia analizowanej inwestycji.

\section{Podstawy hydrologiczne inwestycji}

Najkorzystniejszą lokalizacją nowego portu głębokowodnego na Bałtyku jest miejsce, gdzie przy brzegu głębokość wody wynosi od razu $17 \mathrm{~m}$. Wtedy roboty ziemne i konstrukcyjne związane z budową nabrzeży są ilościowo i cenowo najmniejsze, a do portu nie trzeba wykonywać toru wodnego, jako bezpiecznego dla statków podejścia do portu od strony morza, o gwarantowanej głębokości 17 m na całej długości.

Niestety, na polskim wybrzeżu tak korzystna sytuacja nie występuje, gdyż wody przybrzeżne są płytkie, a ponadto zdarzają się odległe od brzegu ławice, a głębokość wody zmniejsza się nawet do $5 \mathrm{~m}$. Najgorsze warunki są w rejonie Świnoujścia, gdzie tor wodny pogłębiony do głębokości $17 \mathrm{~m}$ (obecnie ma głębokość 13,5 m [www.energetyka24.com]) miałby długość ok. 67 km. W Zatoce Gdańskiej ta długość wynosi od ok. 0,5 km dla portu Hel, pogłębionego do 17 m, do ok. 6 km dla gdańskiego Portu Północnego [biznes.trojmiasto.pl]. 
Na Pomorzu Środkowym, w miarę oddalania się od brzegu, głębokość morza stopniowo zwiększa się, przy czym nie występują ławice. Najmniej korzystny wzrost głębokości, dodatkowo lokalnie zaburzony, występuje na wysokości Kołobrzegu, gdzie głębokość 17 m morze osiagga dopiero w odległości ok. $14 \mathrm{~km}$ od brzegu. Zdecydowanie lepsza sytuacja jest na odcinku wybrzeża między Ustroniem Morskim a Łazami, gdzie ta odległość wynosi ok. 7 km.

Można wstępnie oszacować, że wykonanie podwodnego toru podejścia do nowego portu głębokowodnego o szerokości na dnie 350 m wymagałoby usunięcia osadów dennych o objętości ok. 47,6 mln $\mathrm{m}^{3}$ w przypadku lokalizacji w pobliżu Kołobrzegu albo ok. 23,8 mln m w przypadku portu między Ustroniem Morskim a Łazami. Jeśli osady denne będą gruntami budowlanymi, np. piaskami, to z gruntu wydobytego z dna toru wodnego można będzie usypać nabrzeża portowe. Oznacza to, że z punktu widzenia ekonomicznego (minimalizacji robót ziemnych) lepszą lokalizacją portu byłaby każda lokalizacja na otwartym morzu, tj. na wybudowanym sztucznym półwyspie lub wyspie, albo na jeziorze przybrzeżnym - w porównaniu z lokalizacjami w głębi lądu stałego. Takie lokalizacje „na wodzie” są jednocześnie korzystniejsze z punktu widzenia ograniczenia kolizji z zabudową nadmorską i społecznością lokalną.

\section{Analiza celowości inwestycji}

Zakładając, że dotychczasowy dynamiczny wzrost przeładunków w polskich portach jest tendencją trwała, albo co najmniej długofalowa, budowa lub rozbudowa polskich portów morskich stanie się koniecznością. W kontekście środkowego Pomorza w takim pozytywnym scenariuszu rozwojowym mamy do czynienia z dwoma zasadniczymi wariantami: budować port głębokowodny w rejonie kołobrzesko-koszalińskim lub zaniechać takiej inwestycji. Jest oczywiste, że wybór tej drugiej opcji będzie w tym scenariuszu skutkował albo budową nowego portu głębokowodnego poza środkowym Pomorzem, np. w Elblągu, albo rozbudową istniejących portów w Świnoujściu, Gdyni lub/i Gdańsku.

Biorąc pod uwagę przedstawione wyżej informacje, warto wykonać dla projektu budowy portu na środowym Pomorzu analizę SWOT, która pozwoli uporządkować te informacje i wyciągnąć wnioski ogólne. Taką analizę przedstawiono niżej w formie tabelarycznej (tabela 1). Można byłoby wykonać również analizę SWOT dla wariantu „zerowego" (zaniechanie inwestycji), lecz taka analiza byłaby odwrotnością analizy przeprowadzonej dla wariantu inwestycyjnego (pozytywy zamieniłyby się na negatywy).

W poniższej tabeli zebrane informacje uporządkowano w sposób, jaki stosuje się z reguły w planowaniu przestrzennym, tj. zaliczono odpowiednio kolejno do następujących kategorii:

1. Zasoby środowiska przyrodniczego (w tym hydrologia);

2. Ludność (sieć osadnicza);

3. Gospodarka;

4. Transport. 
Z przedstawionej analizy SWOT wynika, że pozytywy zdecydowanie przeważają nad negatywami, wobec czego wstępnie można przyjąć, że realizacja inwestycji jest celowa, nie zapominając przy tym, że całość tych rozważań dotyczy wyłącznie scenariusza dalszego szybkiego rozwoju gospodarki morskiej.

Tabela 1. Analiza SWOT dla projektu budowy głębokowodnego portu morskiego na środkowym Pomorzu

\begin{tabular}{|c|c|c|}
\hline & Pozytywy & Negatywy \\
\hline 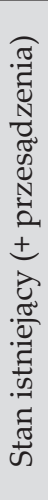 & $\begin{array}{l}\text { S1a: Korzystne warunki hydrograficzne } \\
\text { S2a: Wysoki potencjał ludnościowy } \\
\text { regionu } \\
\text { S2b: Rozwinięta sieć osadnicza (miasta) } \\
\text { S2c: Biegun wzrostu w Koszalinie } \\
\text { S3a: Zaplecze gospodarcze dla inwestycji } \\
\text { S4a: Rozwinięta sieć kolejowa } \\
\text { S4b: Nowa linia kolejowa do CPK (W-wy) } \\
\text { S4c: Droga ekspresowa S6 wzdłuż } \\
\text { wybrzeża } \\
\text { S4d: Plany budowy drogi S11 do Poznania }\end{array}$ & $\begin{array}{l}\text { W1a: Liczne obszary cenne przyrodniczo } \\
\text { W2a: Chaotyczna zabudowa nadmorska }\end{array}$ \\
\hline 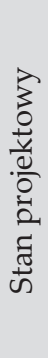 & $\begin{array}{l}\text { O1a: Złagodzenie kolizji przyrodniczych } \\
\text { O2a: Złagodzenie kolizji społecznych } \\
\text { O2b: Przyspieszony rozwój osadnictwa } \\
\text { O3a: Przyspieszony rozwój gospodarczy } \\
\text { O4a: Wykorzystanie rezerw w sieci } \\
\text { kolejowej } \\
\text { O4b: Wykorzystanie rezerw w sieci } \\
\text { drogowej }\end{array}$ & $\begin{array}{l}\text { T1a: Protesty ekologów (np. PLB990003) } \\
\text { T2a: Protesty społeczności lokalnych }\end{array}$ \\
\hline
\end{tabular}

Objaśnienia: $\mathrm{S}=$ mocne strony (strengths); $\mathrm{W}=$ słabe strony (weaknesses); $\mathrm{O}=$ szanse (opportunities); $\mathrm{T}=$ zagrożenia (threats)

\section{Wstępne założenia projektowe}

Port morski buduje się pod konkretne potrzeby zgłaszających się potencjalnych operatorów ruchu towarowego i pasażerskiego, a suma tych potrzeb decyduje o ostatecznej wielkości i kształcie portu oraz zastosowanych rozwiązaniach hydrotechnicznych. W ewentualnych, dalszych etapach przygotowania do realizacji budowy portu na środkowym Pomorzu należałoby podjąć rozmowy i zawrzeć umowy z zainteresowanymi operatorami. Nie czekając na te dalsze etapy, wstępnie można założyć powstanie w ramach portu dwóch baz kontenerowych oraz po jednym terminalu gazowym i naftowym, a także bazy promowej oraz na- 
brzeża dla statków pasażerskich. Oznacza to, że po zakończeniu takiej budowy teren portu zajmowałby ok. $6 \mathrm{~km}^{2}$ powierzchni, w tym ok. $3 \mathrm{~km}^{2}$ przypadałoby na baseny portowe wraz z obrotnicami, a ok. $2 \mathrm{~km}^{2}$ na sztuczny półwysep z nabrzeżami, składowiskami, nasypami, drogami i bocznicami kolejowymi. Taką rezerwę terenu na port przyjęto jako minimalną przy dalszych bardziej szczegółowych studiach lokalizacyjnych.

Jak wspomniano już wcześniej, zakłada się przy tym, że ze względu na lepszy bilans robót ziemnych oraz złagodzenie konfliktów ze społecznościami lokalnymi całość portu zostanie zlokalizowana na terenach pokrytych obecnie wodami, na których zostaną utworzone sztuczny półwysep, baseny portowe i falochrony osłonowe, a tylko dojazd kolejowy i drogowy do portu wymagać będzie wykupienia gruntów na lądzie stałym. We wszystkich wariantach lokalizacyjnych założono wstępnie, że port będzie sąsiadował z wybrzeżem morskim, a jego kształt będzie prostokątem o wymiarach $3 \times 2 \mathrm{~km}$, przy czym jego dłuższe boki zorientowano w kierunku prostopadłym do wybrzeża morskiego, co zmniejsza długość kolizji z naturalnym brzegiem morskim do $2 \mathrm{~km}$.

\section{Wstępne studium lokalizacji inwestycji}

Uwzględniając wyżej podane informacje, można określić wstępnie następujące ogólne lokalizacje dla przedsięwzięcia polegającego na budowie portu morskiego głębokowodnego na Pomorzu Środkowym - dla założonego wyżej programu funkcjonalno-użytkowego inwestycji.

Wariant 1: „Kołobrzeg”

Nie należy odrzucać a priori wariantu rozbudowy istniejącego portu morskiego w Kołobrzegu zamiast budowy nowego portu w sąsiednich lokalizacjach, gdyż dla wariantu "rozbudowa" nie ma istotnych przeciwwskazań przyrodniczych i społeczno-gospodarczych, a nie do pogardzenia jest wystąpienie w przypadku jego realizacji efektu synergii między nową i istniejącą infrastrukturą portową. Jednak przebudowa istniejących basenów portowych zapewniająca obsługę statków o zanurzeniu $15 \mathrm{~m}$ nie wchodzi w rachubę, gdyż obecna głębokość wody przy nabrzeżach portu wynosi $6,5 \mathrm{~m}$, a dopuszczalne zanurzenie statków 4,7 m [pl.wikipedia.org]. Kierując się zatem względami techniczno-ekonomicznymi, lepiej będzie zostawić istniejącą część portu bez zmian, a nowe baseny głębokowodne zlokalizować na otwartym morzu, np. na zachód i północ od istniejącego wejścia do portu.

Zmniejszy to do minimum kolizje $\mathrm{z}$ istniejącą zabudową miasta, ale nie uniknie się ich całkowicie ze względu na konieczność doprowadzenia odpowiednich dróg dojazdowych do nowej części portu; wystąpią kolizje z zabudową mieszkaniową przemysłowo-składową oraz terenami zamkniętymi (wojskowymi); kolizyjność społeczną tego wariantu można szacować na poziomie wysokim. Dodatkowo może wystąpić negatywne oddziaływanie na sąsiadujący bezpośrednio z inwestycją obszar Natura 2000 nr PLH320017; aktualne doku- 
menty planistyczne, w tym Studium uwarunkowań i kierunków zagospodarowania miasta Kołobrzeg [2018], trzeba będzie znacząco zmienić dla terenów w zachodniej części miasta (Załęże, Goryszewo, Kostrzewno).

W wyżej wymienionej lokalizacji portu głębokowodnego, wzdłuż brzegu morskiego, ciągnie się wał wydmowy porośnięty w większości lasem ze wzgórzami pojedynczych wydm, sięgającymi do rzędnej 11 m n.p.m. Dno morza stopniowo opada, osiągając głębokość $10 \mathrm{~m}$ w odległości ok. 1 km od brzegu, po czym dalej jego głębokość zwiększa się znacznie wolniej, osiągając głębokość zaledwie 12-13 m w odległości ok. 4 km od brzegu, a głębokość $20 \mathrm{~m}$ w odległości ok. $18 \mathrm{~km}$.

W związku z takimi warunkami hydrologicznymi orientacyjne zestawienie ilości robót ziemnych będzie się przedstawiało następująco: prace przy budowie toru wodnego do portu obejmą usunięcie ok. $48 \mathrm{mln} \mathrm{m}^{3}$ gruntów z dna morza, budowa nowych basenów portowych przez pogłębienie dna morza oznaczać będzie wybranie ok. $26 \mathrm{mln} \mathrm{m}^{3}$ gruntów, a utworzenie sztucznego półwyspu portowego będzie wymagało wbudowania ok. $17 \mathrm{mln} \mathrm{m}^{3}$ gruntów budowlanych; sumaryczna ilość robót ziemnych wyniesie więc w przybliżeniu $91 \mathrm{mln} \mathrm{m}^{3}$ przemieszczonych osadów dennych.

Zakładając optymistycznie, że wybrane osady denne będą w całości gruntami budowlanymi i zostaną wykorzystane do budowy sztucznego półwyspu, pozostanie nadwyżka ok. $74 \mathrm{mln} \mathrm{m}^{3}$ osadów dennych, którą trzeba będzie odłożyć na dnie morza poza portem i torem wodnym; można przesunąć lokalizację portu dalej w głąb morza, wtedy bilans robót ziemnych trochę poprawi się, ale powoduje to wzrost sumarycznych robót ziemnych, skutkujący podrożeniem kosztów budowy portu.

W sensie regionalnym dojazd kolejowy z głębi lądu do nowej części portu kołobrzeskiego zapewnią istniejące linie kolejowe Piła/Bydgoszcz - Białogard - Kołobrzeg, których przebieg w rejonie nadmorskim nie wymaga korekty z uwagi na wysoką prostoliniowość, a jedynie ewentualnie dobudowy drugiego toru, na który jest miejsce w istniejącym pasie kolejowym. Natomiast dojazd drogowy z głębi lądu zapewnią w okresie przejściowym, tj. w pierwszej fazie budowy portu, drogi ekspresowe S11 Piła - Koszalin oraz S6 Koszalin - Kołobrzeg, które docelowo, tj. w końcowej fazie budowy portu, należałoby uzupełnić o drogę łącznikową (S11A) o przebiegu: Zegrze Pomorskie (S11) - Białogard - Kołobrzeg, długości ok. 46 km, skracającą znacząco długość dojazdu do portu.

Wariant 2: „Pleśna”

W tym wariancie założono budowę portu na otwartym morzu między Ustroniem Morskim a Gąskami w miejscu, gdzie do brzegu morza dochodzą grunty wsi Pleśna (pow. koszaliński, gm. Będzino) i gdzie istnieje dość szeroka przerwa w zabudowie nadmorskiej, pozwalająca bez większych wyburzeń doprowadzić do portu linię kolejową i drogę dojazdową.

Występuje tu na brzegu morza plaża piaszczysta ograniczona od strony lądu klifem o wysokości od $5 \mathrm{~m}$ do 8,5 m w zależności od miejsca, za którym teren opada do rzędnej +1,5 m n.p.m. (łąki) lub do rzędnej 2-4 m n.p.m. (pola), a lokalnie podnosi się do 12,5 m n.p.m. (wy- 
dmy, pagórki). Nie będą konieczne masowe roboty ziemne przy budowie komunikacyjnych szlaków dojazdowych do portu, choć klif trzeba będzie rozciąć płytkim wykopem drogowokolejowym. Dno morza stopniowo opada, osiągając głębokość 10 m w odległości ok. 2 km od brzegu, a głębokość $20 \mathrm{~m}$ w odległości ok. $10 \mathrm{~km}$ od brzegu.

Wąski pas lądu nad morzem, porośnięty lasem, jest tu objęty ochroną przyrodniczą jako obszar Natura nr PLH320017 i nie ma możliwości uniknięcia kolizji z tym obszarem, ale zakłada się, że na podstawie szczegółowej inwentaryzacji przyrodniczej można będzie ustalić najmniej konfliktowe miejsce przecięcia tego obszaru wiązką dojazdowych szlaków transportowych o szerokości całkowitej 40-60 m, i że takie przecięcie nie spowoduje znaczącego negatywnego oddziaływania na ten obszar, oczywiście po zastosowaniu ewentualnych środków minimalizujących.

Szacunek ilości robót ziemnych będzie się przedstawiał następująco: prace przy budowie toru wodnego do portu obejmą usunięcie ok. $24 \mathrm{mln} \mathrm{m}^{3}$ gruntów z dna morza, budowa nowych basenów portowych przez pogłębienie dna morza oznaczać będzie wybranie ok. $32 \mathrm{mln} \mathrm{m}^{3}$ gruntów, a utworzenie sztucznego półwyspu portowego będzie wymagało wbudowania ok. $14 \mathrm{mln} \mathrm{m}^{3}$ gruntów budowlanych; sumaryczna ilość robót ziemnych wyniesie więc ok. $70 \mathrm{mln} \mathrm{m}^{3}$ przemieszczonych osadów dennych.

Zakładając optymistycznie, że wybrane osady denne będą w całości gruntami budowlanymi i zostaną wykorzystane do budowy sztucznego półwyspu, pozostanie nadwyżka ok. $56 \mathrm{mln} \mathrm{m}^{3}$ osadów dennych, którą trzeba będzie odłożyć na dnie morza poza portem i torem wodnym; można przesuwać lokalizację portu dalej w głąb morza, wtedy bilans robót ziemnych stopniowo poprawia się, ale powoduje to stopniowy wzrost sumarycznych robót ziemnych, skutkujący podrożeniem kosztów budowy portu.

W sensie regionalnym dojazd kolejowy z głębi lądu do nowego portu głębokowodnego może zapewnić w okresie przejściowym istniejąca linia kolejowa Kołobrzeg - Koszalin, ale docelowo dojazd kolejowy powinien być wyprostowany przez stworzenie nowej linii kolejowej Wrzosowo - Pleśna, o długości ok. 14 km, połączonej z istniejącymi liniami Piła/ Bydgoszcz - Białogard - Wrzosowo - Kołobrzeg. Natomiast dojazd drogowy z głębi lądu zapewnią w okresie przejściowym drogi ekspresowe S11 Piła - Koszalin oraz S6 Koszalin - Kołobrzeg, które docelowo należałoby uzupełnić o drogę łącznikową (S11A) o przebiegu: Zegrze Pomorskie (S11) - Białogard - Pleśna, długości ok. 35 km, skracającą znacząco długość dojazdu do portu.

Obecnie w pasie potencjalnego dojazdu do portu nie występuje zabudowa mieszkaniowa, z wyjątkiem punktowej i ulicowej rolniczej zabudowy zagrodowej, ale studia uwarunkowań i kierunków zagospodarowania przestrzennego gmin Ustronie Morskie i Będzino [Studium uwarunkowań i kierunków zagospodarowania przestrzennego gminy Ustronie Morskie 2018; Studium uwarunkowań i kierunków zagospodarowania przestrzennego gminy Będzino 2016] przewidują rozwój funkcji mieszkaniowo-turystycznej na obecnych terenach rolniczych, przy zachowaniu bez zmian jedynie istniejącej funkcji leśnej terenu. Nowa zabudowa ma powstać w pasach terenu od Łasina Koszalińskiego do Łopienicy oraz od Kładna przez Pleśnę do Gąsek. Obecny pas nadbrzeżny, wolny od zabudowy o długości ok. $5 \mathrm{~km}$ z punktową 
zabudowa, skróci się do ok. $1 \mathrm{~km}$ - między Wieniotowem a ujściem rzeki Czerwonej do morza, co oznacza, że port na morzu będzie oddziaływał negatywnie na obecną zabudowę punktowa a w przyszłości na skrajne części nowej zwartej zabudowy, głównie wypoczynkowo-turystycznej, obniżając ich walory mieszkaniowe. Obecną kolizyjność społeczną tego wariantu można szacować na poziomie średnim niskim, ale perspektywicznie poziom ten może wzrosnąć do średniego wysokiego.

Wariant 3: "Gąski”

W wariancie 3 przyjęto budowę portu na otwartym morzu między zabudową Gąsek a Sarbinowa (pow. koszaliński, gm. Mielno), tj. w miejscu, gdzie do brzegu morza dochodzą niezabudowane grunty wsi Gąski (część wschodnia) i gdzie istnieje szeroka przerwa w zabudowie nadmorskiej, pozwalająca bez większych wyburzeń doprowadzić do portu linię kolejową i drogę dojazdową. Jest to teren, na którym jeszcze niedawno planowano budowę pierwszej elektrowni atomowej w Polsce, ale inwestor w 2016 r. ostatecznie wycofał się ze wskazania tej lokalizacji, a Wojewoda Zachodniopomorski wygasił wydaną już decyzję lokalizacyjną [www.wnp.pl].

Występuje tu na brzegu morza plaża piaszczysta ograniczona od strony lądu klifem o wysokości od 2,5 m do 7,5 m w zależności od miejsca, za którym teren utrzymuje się na tych rzędnych albo lokalnie podnosi się do 12,3 m n.p.m. (pagórki). Nie wystąpią więc masowe roboty ziemne przy budowie komunikacyjnych szlaków dojazdowych do portu, choć klif trzeba będzie rozciąć płytkim wykopem drogowo-kolejowym. Obszar lądu przylegający do potencjalnej lokalizacji portu nie jest tu objęty ochroną przyrodniczą $w$ formie jakiegokolwiek obszaru Natura 2000. Głębokość morza stopniowo zwiększa się, osiągając rzędną 10 m p.p.m. w odległości ok. 1 km od brzegu, a rzędną 20 m p.p.m. w odległości ok. 8 km od brzegu.

W związku z takimi warunkami hydrologicznymi orientacyjne zestawienie ilości robót ziemnych będzie się przedstawiało następująco: prace przy budowie toru wodnego i nowych basenów portowych obejmą usunięcie ok. $24 \mathrm{mln} \mathrm{m}^{3}$ gruntów z dna morza, budowa nowych basenów portowych przez pogłębienie dna morza oznaczać będzie wybranie ok. $23 \mathrm{mln} \mathrm{m}^{3}$ gruntów, a utworzenie sztucznego półwyspu portowego będzie wymagało wbudowania ok. $20 \mathrm{mln} \mathrm{m}^{3}$ gruntów budowlanych; sumaryczna ilość robót ziemnych wyniesie więc ok. $67 \mathrm{mln} \mathrm{m}^{3}$ przemieszczonych osadów dennych.

Zakładając optymistycznie, że wybrane osady denne będą w całości gruntami budowlanymi i zostaną wykorzystane do budowy sztucznego półwyspu, pozostanie nadwyżka ok. $46 \mathrm{mln} \mathrm{m}^{3}$ osadów dennych, którą trzeba będzie odłożyć na dnie morza poza portem i torem wodnym; można przesuwać lokalizację portu dalej w głąb morza, wtedy bilans robót ziemnych stopniowo poprawia się, ale powoduje to stopniowy wzrost sumarycznych robót ziemnych, skutkujący podrożeniem kosztów budowy portu.

W sensie regionalnym dojazd kolejowy z głębi lądu do nowego portu głębokowodnego może zapewnić w okresie przejściowym istniejąca linia kolejowa Kołobrzeg - Koszalin, ale docelowo dojazd kolejowy powinien być wyprostowany przez stworzenie nowej linii 
kolejowej Wrzosowo - Gąski o długości ok. 15 km, połączonej z istniejącymi liniami Piła/ Bydgoszcz - Białogard - Wrzosowo - Kołobrzeg. Natomiast dojazd drogowy z głębi lądu zapewnią drogi ekspresowe S11 Piła - Koszalin oraz S6 Koszalin - Borkowice (Gąski), których przebieg w rejonie nadmorskim nie wymaga korekty z uwagi na wystarczającą prostoliniowość dojazdu do portu.

Obecnie w pasie potencjalnego dojazdu do portu Studium uwarunkowań i kierunków zagospodarowania przestrzennego gminy Mielno [2010] przewiduje zachowanie istniejącej funkcji rolniczej i leśnej terenu i nie występuje tu zabudowa mieszkaniowa. Jednakże przewidziany w Studium pas nadbrzeżny wolny od zabudowy będzie miał długość zaledwie ok. $860 \mathrm{~m}$, co oznacza, że port na morzu będzie oddziaływał negatywnie na skrajne części nowej zwartej zabudowy, głównie wypoczynkowo-turystycznej w Gąskach (na zachodzie) i Sarbinowie (na wschodzie), obniżając ich walory mieszkaniowe, a zatem wystąpi kolizyjność społeczna tego wariantu na szacowanym poziomie dość wysokim, podobna w skali jak przy zlokalizowaniu tu elektrowni jądrowej.

Wariant 4: „Mielenko"

W wariancie 4. założono budowę portu na otwartym morzu między Chłopami (pow. koszaliński, gm. Mielno) a Mielnem, tj. w rejonie wsi Mielenko (pow. koszaliński, gm. Mielno), gdzie występują przerwy w zabudowie nadmorskiej, pozwalające bez większych wyburzeń doprowadzić do portu linię kolejową i drogę dojazdową. Można tu rozważać dwa podwarianty: na zachód albo na wschód od Mielenka.

Występuje tu na brzegu morza plaża piaszczysta, do której od strony lądu przylega pas wydmowy porośnięty lasem, wyniesiony do ok. 5 m n.p.m. Dalej rozciąga się pas łąk z rzędnymi terenu niewiele większymi od poziomu morza, sztucznie odwadniany za pomocą pompowni, za którym teren podnosi się stopniowo do rzędnych 10-15 m n.p.m. Nie będą konieczne masowe roboty ziemne przy budowie komunikacyjnych szlaków dojazdowych do portu, choć obniżenie łąkowe trzeba będzie przekroczyć niewielkim nasypem, przy czym w podłożu mogą być torfy wymagające wymiany na grunty budowlane. Obszar lądu przylegający do potencjalnej lokalizacji portu nie jest tu objęty ochroną przyrodniczą w formie jakiegokolwiek obszaru Natura 2000. Głębokość morza stopniowo zwiększa się, osiągając rzędną 10 m p.p.m. w odległości ok. 1 km od brzegu, a rzędną 20 m p.p.m. w odległości ok. $10 \mathrm{~km}$ od brzegu.

W związku z powyższymi warunkami hydrologicznymi orientacyjne zestawienie ilości robót ziemnych będzie się przedstawiało następująco: prace przy budowie toru wodnego i nowych basenów portowych obejmą usunięcie ok. $24 \mathrm{mln} \mathrm{m}^{3}$ gruntów z dna morza, budowa nowych basenów portowych przez pogłębienie dna morza oznaczać będzie wybranie ok. $24 \mathrm{mln} \mathrm{m}^{3}$ gruntów, a utworzenie sztucznego półwyspu portowego będzie wymagało wbudowania ok. $20 \mathrm{mln} \mathrm{m}^{3}$ gruntów budowlanych; sumaryczna ilość robót ziemnych wyniesie więc ok. $68 \mathrm{mln} \mathrm{m}^{3}$ przemieszczonych osadów dennych. 
Zakładając optymistycznie, że wybrane osady denne będą w całości gruntami budowlanymi i zostaną wykorzystane do budowy sztucznego półwyspu, pozostanie nadwyżka ok. $48 \mathrm{mln} \mathrm{m}^{3}$ osadów dennych, którą trzeba będzie odłożyć na dnie morza poza portem i torem wodnym; można przesuwać lokalizację portu dalej w głąb morza, wtedy bilans robót ziemnych stopniowo poprawia się, ale powoduje to stopniowy wzrost sumarycznych robót ziemnych, skutkujący podrożeniem kosztów budowy portu.

W sensie regionalnym dojazd kolejowy z głębi lądu do nowego portu głębokowodnego może zapewnić w okresie przejściowym istniejąca linia kolejowa Kołobrzeg - Koszalin, ale docelowo dojazd kolejowy powinien być wyprostowany przez stworzenie nowej linii kolejowej Dunowo - Mielenko o długości ok. 16 km, tworzącej zachodnią obwodnicę Koszalina, połączonej z istniejącymi liniami Piła/Bydgoszcz - Białogard - Dunowo - Koszalin. Natomiast dojazd drogowy z głębi lądu zapewnią drogi ekspresowe S11 Piła - Koszalin oraz S6 Koszalin - Dobre (Mielenko), których przebieg w rejonie nadmorskim nie wymaga korekty z uwagi na wystarczająca prostoliniowość dojazdu do portu.

Obecnie w pasie potencjalnego dojazdu do portu Studium uwarunkowań i kierunków zagospodarowania przestrzennego gminy Mielno [2010] przewiduje zachowanie istniejącej funkcji rolniczej i leśnej terenu między Chłopami a Mielenkiem, ale niezgodnie z tym studium następuje stopniowa zabudowa terenów w całym pasie Chłopy - Mielenko - Mielno, gdzie powstała już pasmowa, rozproszona wśród pól zabudowa mieszkaniowa, o szerokości zmiennej 400-800 m, kolidująca z ewentualnymi szlakami dojazdowymi do portu. Realna kolizyjność społeczna tego wariantu jest więc wysoka, choć formalnie nie powinna praktycznie wystąpić.

Wariant 5: „Jezioro Jamno”

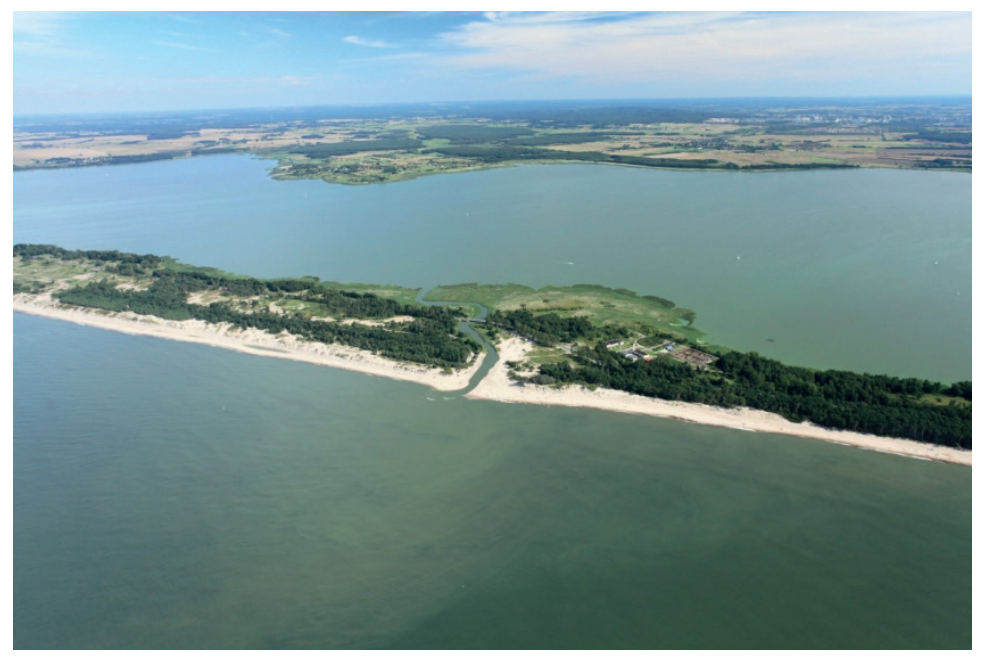

Ryc. 1. Widok na środkową część Jeziora Jamno, planowaną opcjonalnie do zajęcia pod port morski Źródło: M. Karasiński - pwr.com.pl 
W odróżnieniu od pozostałych wariantów w tym wariancie założono budowę portu nie na otwartym morzu, lecz na wodach przybrzeżnego Jeziora Jamno, przy czym konieczne będzie przekopanie mierzei oddzielającej to jezioro od morza. Wstępnie wybrano na miejsce przekopu teren między końcem zabudowy Mielna a oczyszczalnią ścieków (ryc. 1, przy prawej krawędzi zdjęcia), gdzie mierzeja ma najmniejszą szerokość - ok. $250 \mathrm{~m}$, w tym pas wydmowy ok. 100 m. Można również rozważać przekopanie mierzei po drugiej, wschodniej stronie Jamieńskiego Nurtu, zapewniającego odpływ wód z jeziora do morza.

W miarę oddalania się od brzegu morskiego dno morza opada, osiągając rzędną $10 \mathrm{~m}$ p.p.m. w odległości ok. $1 \mathrm{~km}$ od brzegu, a rzędną 20 m p.p.m. w odległości ok. $10 \mathrm{~km}$ od brzegu. Trzeba będzie tu wykonać tor wodny prowadzący do przekopu przez mierzeję.

Na mierzei występuje wał wydmowy, o zmiennej szerokości, porośnięty w większości lasem. W zachodniej części mierzei występuje zwarta zabudowa Mielna (Unieścia), a we wschodniej teren objęty jest ochroną przyrodniczą jako obszar Natura nr PLH320041, przy czym nie ma możliwości uniknięcia kolizji z tym obszarem. Warto jednocześnie podkreślić, że w tym wariancie kolizja z obszarem nr PLB990003 będzie najmniejsza w stosunku do pozostałych wariantów, gdyż dotyczyć będzie tylko lokalizacji toru wodnego w tym obszarze, a nie całego terenu portu.

Jezioro Jamno nie jest objęte ochroną w sieci Natura 2000, nie ma więc większych przeszkód przyrodniczych, aby część jeziora zasypać, a część pogłębić, tworząc tu port morski. Wstępnie na teren portu wybrano środkową część jeziora między Unieściem a osiedlem Jamno w mieście Koszalin, którego granica administracyjna sięga tu brzegu jeziora, gdzie w kierunku prostopadłym do brzegu morza jezioro ma szerokość $3 \mathrm{~km}$, a jego głębokość dochodzi do $7 \mathrm{~m}$ (średnio $3 \mathrm{~m}$ ). Przewiduje się zajęcie na port całej szerokości jeziora i stworzenie grobli portowych łączących mierzeję z lądem stałym po obu stronach portu i przekopu. Takie rozwiązanie projektowe będzie zgodne ze Studium uwarunkowań i kierunków zagospodarowania przestrzennego miasta Koszalina [2014], w którym stwierdzono, że jednym z głównych założeń rozwoju miasta będzie „rozwój związków z morzem poprzez oś rozwojową w kierunku jeziora Jamno" (tom II, s. 7), a ponadto zapewni zachowanie obecnej rzędnej lustra wody w jeziorze (0,1 m n.p.m.) na niezmienionym poziomie, przy czym część jeziora zajęta na port będzie połączona z morzem kanałem otwartym, bez śluz.

Orientacyjne zestawienie ilości robót ziemnych będzie się przedstawiało następująco: budowa toru wodnego na otwartym morzu: ok. $24 \mathrm{mln} \mathrm{m}^{3}$ gruntów usuniętych z dna morza; przekopanie mierzei: ok. $2 \mathrm{mln} \mathrm{m}^{3}$ gruntów usuniętych z mierzei; budowa basenów portowych: ok. $42 \mathrm{mln} \mathrm{m}^{3}$ gruntów usuniętych $\mathrm{z}$ dna jeziora; budowa nabrzeży i grobli portowych: ok. $10 \mathrm{mln} \mathrm{m}^{3}$ wbudowanych gruntów budowlanych; sumaryczna ilość robót ziemnych wyniesie więc ok. $78 \mathrm{mln} \mathrm{m}^{3}$ przemieszczonych osadów dennych.

Zakładając optymistycznie, że wybrane osady denne morskie i jeziorne będą w całości gruntami budowlanymi i zostaną wykorzystane do budowy sztucznego półwyspu, bilans robót ziemnych zamknie się nadwyżką ok. $68 \mathrm{mln} \mathrm{m}^{3}$ osadów dennych, które trzeba będzie odłożyć na dnie morza poza torem wodnym albo przeznaczyć na zasypanie części jeziora poza zasadniczym portem, np. poszerzając odpowiednio groble portowe. 
W sensie regionalnym dojazd kolejowy z głębi lądu do nowego portu głębokowodnego zapewnią istniejące linie kolejowe Piła/Bydgoszcz - Białogard - Koszalin, które zasadniczo nie wymagają korekty (wyprostowania), a jedynie uzupełnienia o odcinek Koszalin - Jamno - Port o długości ok. 6 km. Natomiast dojazd drogowy z głębi lądu zapewnią drogi ekspresowe S11 Piła - Koszalin oraz S6 Koszalin (Bielice) - Koszalin Wschód (Jamno), których przebieg $\mathrm{w}$ rejonie nadmorskim nie wymaga korekty z uwagi na wystarczającą prostoliniowość dojazdu do portu.

Ewentualne wprowadzenie inwestycji do planów przestrzennych będzie wymagało zmiany studiów uwarunkowań i kierunków rozwoju przestrzennego zarówno dla gminy Mielno (jezioro i mierzeja) [Zmiana studium uwarunkowań i kierunków zagospodarowania przestrzennego gminy Mielno 2010], jak i dla miasta Koszalina (dojazd kolejowy i drogowy) [Studium uwarunkowań i kierunków zagospodarowania przestrzennego miasta Koszalina ze zmianami 2014], przy czym z uwagi na małą kolizyjność inwestycji z istniejącą i planowaną zabudową mieszkaniową nie przewiduje się wystąpienia znaczących protestów społecznych.

\section{Ocena wariantów lokalizacyjnych}

Zwykle dla planowanych inwestycji transportowych wykonuje się ekonomiczną ocenę wariantów lokalizacyjnych metodą kosztów i korzyści. Jednak tutaj chodziłoby raczej o bardziej ogólną ocenę przedmiotowej inwestycji, w której uwzględniono by, obok kryteriów ekonomicznych, także trudne do wyceny skutki społeczno-ekologiczne inwestycji. W takich generalnych ocenach stosuje się analizę wielokryterialną [Stadia i skład... 2009], która pozwala na uszeregowanie wariantów inwestycyjnych od najlepszego do najgorszego na podstawie cząstkowych ocen stopnia spełnienia przyjętych kryteriów.

Dla analizowanej inwestycji przyjęto ocenę wyżej wymienionych wariantów lokalizacyjnych za pomocą analizy wielokryterialnej, przy czym w tej analizie zastosowano najprostszą metodę punktowej oceny stopnia spełnienia kryteriów. Ustalono skalę 0-10 pkt, przy czym 0 pkt przyznawano w przypadku najbardziej negatywnej oceny, a 10 pkt w przypadku najbardziej pozytywnej oceny.

W takiej analizie wykorzystano zebrane wyżej informacje szczegółowe o poszczególnych wariantach lokalizacyjnych inwestycji, przy czym dane te uporządkowano w sposób, jaki stosuje się z reguły w planowaniu inwestycji transportowych, tj. odniesiono do następujących kryteriów oceny inwestycji (w nawiasach wyjaśniono bardziej szczegółowo sposób mierzenia stopnia spełnienia tych kryteriów, związany ściśle z dostępnością danych wejściowych):

1. Kryterium przestrzenno-urbanistyczne (wpływ na sieć osadniczą);

2. Kryterium transportowe (łatwość dojazdu z portu do centrum kraju i odwrotnie);

3. Kryterium techniczno-funkcjonalne (długość toru wodnego podejścia do portu);

4. Kryterium ekonomiczne (koszty inwestycyjne mierzone ilością robót ziemnych);

5. Kryterium przyrodnicze (wpływ na obszary sieci Natura 2000);

6. Kryterium społeczne (spodziewany poziom protestów społecznych). 
Przyjęto, że powyższe kryteria będą miały równą wagę (stopień ważności) w ocenie sumarycznej, co oznacza, że nie mnożono punktowych ocen cząstkowych przez współczynniki wagowe, a po prostu oceny te sumowano. Wynik takiej zgrubnej analizy i oceny wielokryterialnej przedstawiono $\mathrm{w}$ tabeli 2.

Z tak skonstruowanej analizy wielokryterialnej wynika, że zdecydowanie najlepszą lokalizacją portu morskiego będzie wariant 5. „Jezioro Jamno”, a pod uwagę można również brać drugą w kolejności najlepszą lokalizację, tj. wariant 4. „Mielenko”. Oba te warianty wzmacniają funkcję osadniczą miasta Koszalin, co jest w pełni zgodne z planem wojewódzkim (biegun wzrostu w Koszalinie). Inne zalety tych wariantów to łatwość doprowadzenia dojazdów kolejowo-drogowych do portu oraz korzystne warunki hydrologiczne, tj. głębokie morze bez płycizn i ławic. Warianty te różnicuje przede wszystkim konfliktowość społeczna: wysoka dla wariantu 4. i niska dla wariantu 5.

Najgorzej wypadł wariant 1 . „Kołobrzeg”, dlatego proponuje się go odrzucić, przystępując do ewentualnych dalszych studiów lokalizacyjnych. Niska ocena tego wariantu wynika przede wszystkim z występowania rozległej płycizny morskiej przed portem, co powoduje wysokie koszty inwestycyjne i utrudni statkom wejście do portu oraz z trudności przeprowadzenia adekwatnego dojazdu do nowej części portu przez zabudowane tereny miasta, co skutkuje wysoką konfliktowością społeczną wariantu.

Tabela 2. Wstępna analiza wielokryterialna dla wariantów lokalizacji głębokowodnego portu morskiego na środkowym Pomorzu

\begin{tabular}{|l|c|c|c|c|c|}
\hline \multicolumn{1}{|c|}{ Kryteria oceny } & W1 & W2 & W3 & W4 & W5 \\
\hline K1. Kryterium przestrzenno-urbanistyczne & 5 & 0 & 0 & 3 & 10 \\
\hline K2. Kryterium transportowe & 5 & 2 & 0 & 9 & 10 \\
\hline K3. Kryterium techniczno-funkcjonalne & 0 & 10 & 10 & 10 & 10 \\
\hline K4. Kryterium ekonomiczne & 0 & 9 & 10 & 10 & 5 \\
\hline K5. Kryterium przyrodnicze & 3 & 0 & 9 & 10 & 8 \\
\hline K6. Kryterium społeczne & 0 & 4 & 2 & 0 & 10 \\
\hline Razem wszystkie kryteria K1-K6 & 13 & 25 & 31 & 41 & 53 \\
\hline
\end{tabular}

Objaśnienia: $\mathrm{W}=$ wariant $\mathrm{nr}$

Źródło: opracowanie własne

\section{Podsumowanie}

Przedstawione wyżej wstępne studium wykonalności inwestycji dotyczącej budowy morskiego portu głębokowodnego na środkowym Pomorzu wykazało, że realizacja takiego przedsięwzięcia jest celowa przy założeniu utrzymania się dalszego dynamicznego wzrostu przeładunków w polskich portach morskich. Lepszym rozwiązaniem jest budowa nowego portu na środkowym Pomorzu niż inwestowanie w rozbudowę istniejących dużych portów 
(Szczecin, Świnoujście, Gdynia i Gdańsk), ponieważ wtedy dowóz towarów statkami równomierniej rozłoży się wzdłuż polskiego wybrzeża Bałtyku, a jednocześnie zostaną w pełni wykorzystane istniejące i planowane systemy transportowe służące do ewentualnego wywozu towarów z nowego portu w głąb lądu i odwrotnie.

Wykonane uproszczone studium lokalizacji nowego portu doprowadziło do wniosku, że najlepszą lokalizacją portu głębokowodnego na środkowym Pomorzu byłby wariant 5 . „Jezioro Jamno", zakładający budowę portu w środkowej części tego jeziora z jednoczesnym przekopaniem wąskiej mierzei oddzielającej jezioro od Bałtyku. Alternatywnym wskazaniem lokalizacyjnym mógłby być nieco gorszy wariant 4 . „Mielenko”, w którym port powstałby na otwartym morzu, na wysokości tej miejscowości, czyli między Chłopami a Mielnem. W obu tych wariantach infrastruktura portowa i ewentualne lądowe zaplecze portu łączyłyby się przestrzennie z terenami miejskimi Koszalina, tworząc z tym miastem powiększoną aglomerację o dużym potencjale rozwojowym.

Należy się jednak zastrzec, że na tak wstępnym etapie planowania tak dużej inwestycji wykonane analizy i oceny celowości oraz ewentualnej optymalnej lokalizacji przedsięwzięcia muszą być siłą rzeczy bardzo uproszczone, gdyż kształt inwestycji może być określony jedynie schematycznie (z powodu braku wielu istotnych danych wejściowych i szczegółowych rozwiązań projektowych). Oznacza to, że ewentualne dalsze bardziej szczegółowe analizy i oceny mogą prowadzić do odmiennych wniosków niż przedstawione wyżej.

\section{Literatura}

Studium uwarunkowań i kierunków zagospodarowania przestrzennego miasta Kołobrzeg (tekst ujednolicony), 2018, Urząd Miasta Kołobrzeg, Wydział Urbanistyki i Architektury.

Studium uwarunkowań i kierunków zagospodarowania przestrzennego gminy Ustronie Morskie, 2018, Wójt Gminy Ustronie Morskie.

Studium uwarunkowań i kierunków zagospodarowania przestrzennego gminy Będzino (jednolity tekst), 2016, Wójt Gminy Będzino.

Zmiana studium uwarunkowań i kierunków zagospodarowania przestrzennego gminy Mielno, 2010, Wójt Gminy Mielno.

Studium uwarunkowań i kierunków zagospodarowania przestrzennego miasta Koszalina ze zmianami, 2014, Miasto Koszalin.

Stadia i skład dokumentacji projektowej dla dróg i mostów w fazie przygotowania zadań. Załącznik do zarządzenia nr 17 Generalnego Dyrektora Dróg Krajowych i Autostrad z dnia 11.05.2009 r.

Ustawa z dnia 9 sierpnia 2019 r. o inwestycjach w zakresie budowy portów zewnętrznych (Dz.U. z 2019 r. poz. 1924). 
Uchwała RM w sprawie przyjęcia Koncepcji Przestrzennego Zagospodarowania Kraju 2030 (M.P. z 2012 r. poz. 252).

Uchwała Nr LXV/530/10 Sejmiku Województwa Zachodniopomorskiego z dn. 19.10.2010 r.

\section{Strony internetowe}

https://biznes.trojmiasto.pl/Urzad-Morski-zmodernizuje-tor-wodny-do-PortuPolnocnego-n129277.html

http://geoserwis.gdos.gov.pl/mapy/

https://pl.wikipedia.org/wiki/Port_morski_Ko\%C5\%82obrzeg

http://rbgp.pl/pzpwz-wiecej-informacji/

http://trojmiasto.wyborcza.pl/trojmiasto/7,35612,24388285,czwarte-miejsce-na-baltyku-poznalismy-wyniki-portu-gdansk-za.html

https://www.energetyka24.com/glebokosc-sporu-czyli-dwa-slowa-o-gazoporcie

http://www.eswinoujscie.pl/2017/06/14/zobacz-moze-wygladac-terminal-kontenerowyporcie-zewnetrznym-swinoujsciu/

https://www.portalmorski.pl/porty-logistyka/38509-gdynia-glebokowodna-czyli-lepiejpozno-niz-wcale

https://www.portalmorski.pl/porty-logistyka/42174-mgmizs-planowany-terminalkontenerowy-w-swinoujsciu-przeladuje-rocznie-1-5-mln-teu

http://www.portgdansk.pl/zegluga/warunki-hydrograficzne

http://www.port.szczecin.pl/pl/spolka/strategia-i-rozw\%C3\%B3j/rozw\%C3\%B3j/125m-dla-szczecina/

https://www.rynekinfrastruktury.pl/wiadomosci/porty/port-gdansk-w-2019-r-zanotowalwzrost-o-64-proc-rok-do-roku-70561.html

https://www.wnp.pl/energetyka/zapadla-ostateczna-decyzja-ws-budowy-elektrowniatomowej-w-gaskach,278055_1_0_0.html [wszystkie strony internetowe dostępne w maju 2020]. 


\section{The advisability of building the deepwater seaport in Central Pomerania \\ Preliminary study}

\section{ABSTRACT}

The main seaports in Poland have unfortunate locations, only at the western or eastern end of the Polish Baltic coast, i.e. at the Odra river mouth or at the Vistula river mouth (estuary) and the distance between them is $280-290 \mathrm{~km}$ (in a straight line). Therefore, the construction of a fourth deepwater port is worth considering. It should be located roughly in the middle, somewhere in central Pomerania. The preferred location is on the coastal section between the major cities of that part of Pomerania, i.e. Kołobrzeg and Koszalin.

The article presents an analysis of, transport, natural and hydrographic con-ditions. The arguments for and against such an investment are presented. Finally - after determining the advisability of the investment - investment locations are indicated (assessed using a multi-criteria approach) and the optimal location is chosen.

The SWOT analysis shows that the positive aspects of building a new port definitely outweigh the negatives, so it was initially assumed that realizing the project is reasonable. However, these conclusions are only applicable in the assumed scenario of the further rapid development of the maritime economy in Poland.

Under the preliminary assumption of the advisability of building a new seaport, the general investment program was defined. Two container bases are planned to be built within the port in the target period - one gas and one oil terminal, as well as a ferry base and quay for passenger ships. This means that after the completion of the project, the port area would cover about $6 \mathrm{~km}^{2}$, including about $3 \mathrm{~km}^{2}$ of port basins (including turntables), and ca. $2 \mathrm{~km}^{2}$ of an artificial peninsula with quays, storage yards, roads and railway sidings.

The following locations for the analysed project were initially defined: "Kołobrzeg", "Pleśna", "Gąski", "Mielenko" and "Jamno Lake". Next, basic data were collected characterising each variant hydrological, technical, economic and environmental terms. As a result of the multi-criteria analysis, the $5^{\text {th }}$ variant - "Jamno Lake" was identified as by far the best location for the seaport. The second best location, i.e. the $4^{\text {th }}$ variant - "Mielenko", may also be taken into account. Both of these options strengthen the settlement function of the city of Koszalin, which is in line with the regional spatial development plan's provisions concerning the planned growth pole in Koszalin.

Key words: water transportation, construction of seaports, optimisation of the location of transport investments, feasibility studies, hydrology, environmental protection

Tadeusz Wójcicki, dr inż., prof. WSEiZ - specjalizuje się w planowaniu i projektowaniu sieci transportowych; biegły w zakresie sporządzania ocen oddziaływania na środowisko; profesor na Wydziale Architektury Wyższej Szkoły Ekologii i Zarządzania w Warszawie; kontakt do autora:WSEiZ, ul. Olszewska 12,00-792 Warszawa, tadeuszwojcicki@o2.pl

Tadeusz Wójcicki, PhD Eng, associate professor at WSEiZ - specialises in the planning and design of transport networks; expert in the field of environmental impact assessment; professor at the Faculty of Architecture at the University of Ecology and Management in Warsaw (WSEiZ); contact to the author: WSEiZ, ul. Olszewska 12, 00-792 Warszawa 